\title{
Origin of diamondiferous Torngat ultramafic lamprophyres and the role of multiple MARID-type and carbonatitic vein metasomatized cratonic mantle in the genesis of $\mathrm{SiO}_{2}$-poor potassic melts
}

\author{
Sebastian Tappe ${ }^{1,2}$, Stephen F. Foley ${ }^{3}$, Bruce A. Kjarsgaard ${ }^{4}$, Rolf L. Romer ${ }^{5}$, Larry M. \\ Heaman $^{1}$, Andreas Stracke ${ }^{6}$, George A. Jenner ${ }^{7}$ \\ ${ }^{1}$ Department of Earth and Atmospheric Sciences, University of Alberta, Edmonton, Alberta, Canada \\ ${ }^{2}$ De Beers Canada Inc., Toronto, Ontario, Canada \\ ${ }^{3}$ Institut für Geowissenschaften, Johannes Gutenberg-Universität, Mainz, Germany \\ ${ }^{4}$ Geological Survey of Canada, Ottawa, Ontario, Canada \\ ${ }^{5}$ GeoForschungszentrum Potsdam, Telegrafenberg, Potsdam, Germany \\ ${ }^{6}$ Institut für Isotopengeologie und Mineralische Rohstoffe, ETH, Zürich, Switzerland \\ ${ }^{7}$ Department of Earth Sciences, Memorial University, St. John's, Newfoundland and Labrador, Canada
}

\section{Multiply metasomatized cratonic mantle}

There exists a general consensus that cratonic MARIDtype and carbonate-bearing veins in peridotite can be the respective sources for lamproite and carbonatite magmas when present as the sole metasome. In this contribution we present the case for concurrent melting of two such contrasting metasomatic assemblages that had been introduced into the North Atlantic craton mantle lithosphere at different times. The outcome was a suite of carbonate-potassic silicate magmas, the Torngat ultramafic lamprophyres (UML) of northern Labrador and eastern Quebec (Canada), which form the largest known diamondiferous UML dyke swarm worldwide (Tappe et al., 2004; 2008). We demonstrate that multiple MARID-type and carbonatitic vein metasomatized cratonic mantle bears innumerable possibilities for transitions between primary carbonate and potassic silicate magmas. This, along with regional variations and peculiarities in vein mineralogy, is likely one of the main reasons why almost every craton has developed a 'unique' suite of mantle-derived potassic magma compositions imposing difficulties to diamond exploration programs and modern systematics of igneous rocks (Tappe et al., 2005; Mitchell, 2006).

\section{Results}

Torngat UML/carbonatite magmatism occurred between $c a$. 610 and 565 Ma (Fig.1) and was coeval with UML/carbonatite activity at Aillik Bay in central Labrador (Tappe et al., 2006; 2007) and in the Sisimiut-Sarfartoq areas of West Greenland (Larsen and Rex, 1992), as well as kimberlite magmatism in the West Greenland Maniitsoq area (Nielsen and Jensen, 2005) and the central Quebec Otish Mountains (Birkett et al., 2004). The coeval Late Neoproterozoic deep volatile-rich magmatism of once-contiguous eastern Canada and West Greenland is well displayed in the $\mathrm{U}-\mathrm{Pb}$ geochronology summary in Figure 1.

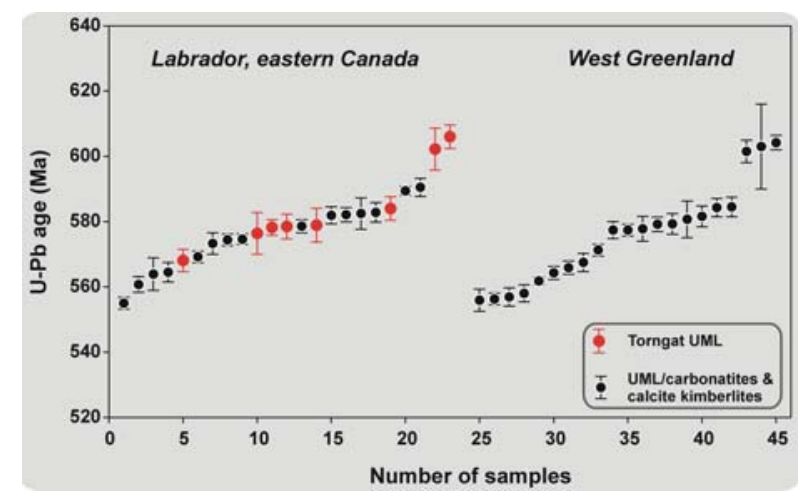

Figure 1: Histogram of ${ }^{206} \mathrm{~Pb} /{ }^{238} \mathrm{U}$ perovskite and pyrochlore ages for Late Neoproterozoic $U M L /$ carbonatite and calcite kimberlite intrusives from eastern Canada (Tappe et al., 2006; 2008) and West Greenland (Heaman, unpublished). Error bars correspond to $2 \sigma$ uncertainties.

The Torngat carbonate-rich aillikite/carbonatite and carbonate-poor mela-aillikite dyke varieties show a large spread in Sr-Nd-Hf-Pb isotope ratios with pronounced correlations between isotope systems (Fig.2). An isotopically depleted component is identified solely within aillikites $\left({ }^{87} \mathrm{Sr} /{ }^{86} \mathrm{Sr}_{\mathrm{i}}=0.70323\right.$ 0.70377; $\varepsilon \mathrm{Nd}_{\mathrm{i}}=+1.2$ to $+1.8 ; \varepsilon \mathrm{Hf}_{\mathrm{i}}=+1.4$ to +3.5 ; ${ }^{206} \mathrm{~Pb} /{ }^{204} \mathrm{~Pb}_{\mathrm{i}}=18.2-18.5$ ), whereas some aillikites and all mela-aillikites range to more enriched isotope signatures $\left({ }^{87} \mathrm{Sr} /{ }^{86} \mathrm{Sr}_{\mathrm{i}}=0.70388-0.70523 ; \varepsilon \mathrm{Nd}_{\mathrm{i}}=-0.5\right.$ to -3.9; $\varepsilon \mathrm{Hf}_{\mathrm{i}}=-0.6$ to $-6.0 ;{ }^{206} \mathrm{~Pb} /{ }^{204} \mathrm{~Pb}_{\mathrm{i}}=17.8-18.2$ ) approaching compositions of 1400-1200 Ma olivine lamproites from the region (Fig.2). 


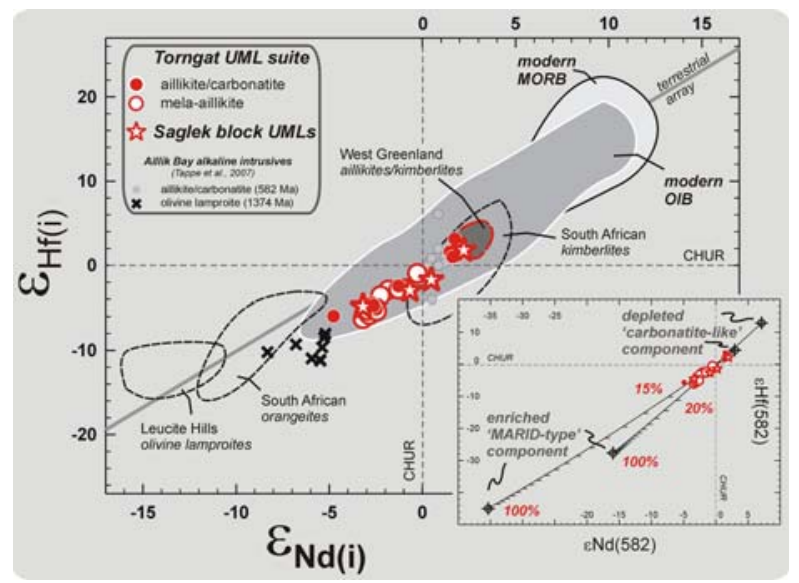

Figure 2: Initial $\varepsilon H f$ vs. $\varepsilon N d$ for Torngat and neighbouring Saglek block aillikite/carbonatite and mela-aillikite dykes from northern Labrador. The inset shows two mixing hyperbolae constructed between isotopically depleted radiogenic components (proxy for convective mantle-derived carbonate melt) and isotopically enriched unradiogenic components (proxy for MARID-type metasomatized cratonic mantlederived potassic melt). Details of the modelling and data sources can be found in Tappe et al. (2008).

These contrasting isotopic characteristics of aillikites/carbonatites and mela-aillikites, along with subtle differences in their modal carbonate and bulkrock $\mathrm{SiO}_{2}, \mathrm{Al}_{2} \mathrm{O}_{3}, \mathrm{Fe}_{2} \mathrm{O}_{3} / \mathrm{FeO}, \mathrm{Na}_{2} \mathrm{O}$, Zr-Hf, and Cs-Rb contents and/or ratios (Fig.3), are consistent with two distinctive metasomatic assemblages of different age in the mantle magma source region.

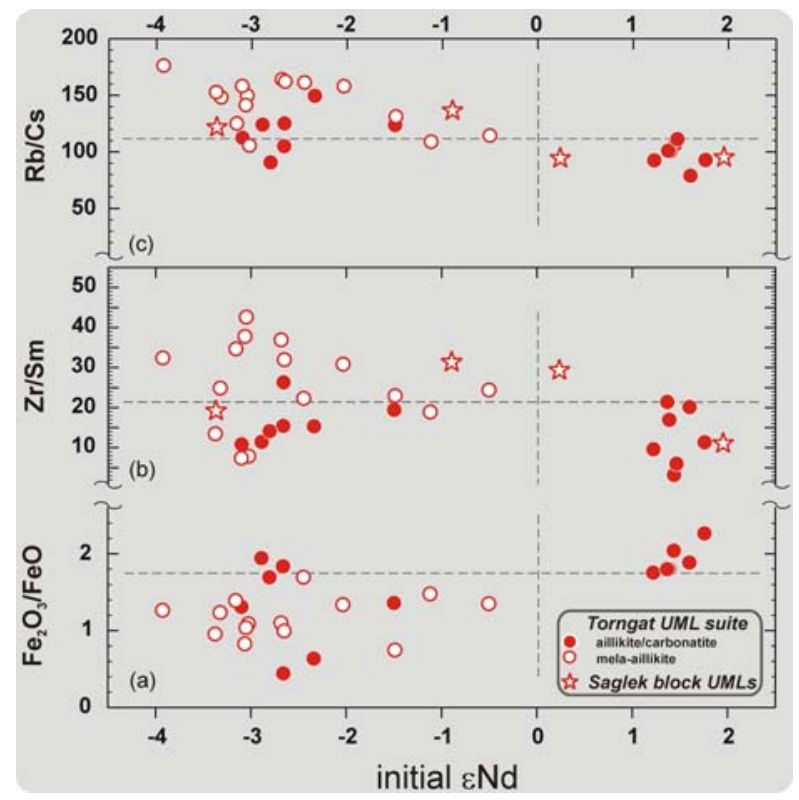

Figure 3: $\mathrm{Fe}_{2} \mathrm{O}_{3} / \mathrm{FeO}$ (a) and incompatible trace element ratios $(\boldsymbol{b}-\boldsymbol{c})$ vs. initial $\varepsilon N d$ of the Torngat and Saglek block aillikite/carbonatite and mela-aillikite dykes. Note the subtle differences between the isotopically depleted (positive $\varepsilon N d$ ) and enriched samples (negative $\varepsilon N d$ ).

\section{Petrogenesis of the Torngat UML}

Integration of petrologic, geochemical, and isotopic information leads us to propose that the isotopically enriched component originated from a reduced phlogopite-richterite-Ti-oxide dominated source assemblage that formed prior to $1400 \mathrm{Ma}$ and is reminiscent of MARID suite xenoliths. In contrast, the isotopically most depleted aillikites/carbonatites reveal systematically younger $\mathrm{Nd}$ and $\mathrm{Hf}$ model ages and show elevated $\mathrm{Fe}_{2} \mathrm{O}_{3} / \mathrm{FeO}$ (Fig.3) consistent with derivation from a younger, more oxidized phlogopitecarbonate dominated source assemblage.

We argue that low-degree $\mathrm{CO}_{2}$-rich potassic silicate melts from the convective upper mantle were preferentially channelled into an older, pre-existing MARID-type vein network at the base of the North Atlantic craton lithosphere, where they froze to form new phlogopite-carbonate dominated veins. Continued stretching and thinning of the cratonic lithosphere during the Late Neoproterozoic remobilized the carbonate-rich vein material and induced volatilefluxed fusion melting of the MARID-type veins and the host peridotite substrate (Fig.4).

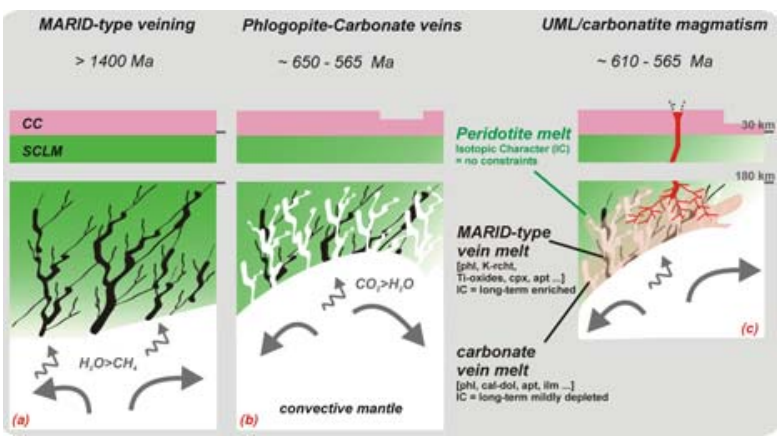

Figure 4: Cartoon illustrating the petrogenesis of the Torngat UML/carbonatite hybrid magma spectrum: (a) Formation of MARID-type veins within lower reaches of the cratonic lithosphere before ca. $1400 \mathrm{Ma}$, presumably during the Paleoproterozoic. (b) Injection of oxidized low-degree $\mathrm{CO}_{2}$-rich convective mantlederived melts into the pre-existing, reduced cratonic vein network shortly prior to and subsequently to ca. $610 \mathrm{Ma}$; these injections produced the phlogopitecarbonate dominated veins. (c) Remelting of these carbonate-rich veins, which triggered volatile-fluxed melting of old hydrous MARID-type veins and the concomitant fusion of cratonic peridotite; this produced the Torngat aillikite/carbonatite and melaaillikite magma spectrum at ca. 610-565 Ma.

Isotopic modelling suggests that only 5-12 \% trace element contribution from such geochemically extreme MARID-type material is required to produce the observed compositional shift from the isotopically most depleted aillikites/carbonatites towards enriched mela-aillikites (Fig.2). This model is a variant of the generally accepted vein-plus-wall-rock melting mechanism for the generation of lamproite magmas (Foley, 1992) and seeks to explain potassic magma 
types at the low- $\mathrm{SiO}_{2}$ end ( $<40 \mathrm{wt} . \%$ ) of the alkaline rock spectrum, which typically contain primary carbonate and may be associated with carbonatites. The model presented here reiterates the message that mixed, or veined, mantle source regions are necessary for the generation of highly alkaline melts, because volatile-present melting of peridotite alone fails to explain their compositions.

\section{Origins of $\mathrm{SiO}_{2}$-poor diamondiferous potassic melts}

We conclude that cold cratonic mantle lithosphere can host several generations of contrasting vein assemblages, and that each may have formed during past tectonic and magmatic events under distinctively different physicochemical conditions (Fig.4). However, it appears that the lower thermal stability of carbonatebearing assemblages drastically limits the lifetime of carbonate-bearing veins compared to carbonate-free vein assemblages such as MARID. This difference may help to explain the typically observed contrasting isotope signatures of otherwise similarly strong incompatible element enriched UML/carbonatite and lamproite magmas. Significant long-term radiogenic in-growth is characteristic for the MARID-type metasomatic vein assemblages of 'anorogenic' lamproites, whereas it is not facilitated within relatively short-lived carbonate-bearing vein assemblages of cratonic UML/carbonatites.

Although cratonic MARID-type and carbonate-bearing veins in peridotite can be the respective sources for lamproite and UML/carbonatite magmas when present as the only enrichment, their concomitant fusion in a complex source region may give rise to a whole new variety of deep volatile-rich magmas and we suggest that Group 2 kimberlites (orangeites), kamafugites, and certain types of ultramafic lamprophyre are formed in this manner.

\section{References}

Birkett, T.C., McCandless, T.E. and Hood, C.T., 2004. Petrology of the Renard igneous bodies: host rocks for diamond in the northern Otish Mountains region, Quebec. Lithos, 76: 475490.

Foley, S.F., 1992. Vein-plus-wall-rock melting mechanism in the lithosphere and the origin of potassic alkaline magmas. Lithos, 28: 435453.

Larsen, L.M. and Rex, D.C., 1992. A review of the 2500 Ma span of alkaline-ultramafic, potassic and carbonatitic magmatism in West Greenland. Lithos, 28: 367-402.

Mitchell, R.H., 2006. Potassic magmas derived from metasomatized lithospheric mantle: nomenclature and relevance to exploration for diamond-bearing rocks. Journal of the Geological Society of India, 67(3): 317-327.
Nielsen, T.F.D. and Jensen, S.M., 2005. The Majuagaa calcite-kimberlite dyke, Maniitsoq, southern West Greenland. Report - Geological Survey of Denmark and Greenland, 2005/43: 1-59.

Tappe, S., Jenner, G.A., Foley, S.F., Heaman, L.M., Besserer, D., Kjarsgaard, B.A. and Ryan, B., 2004. Torngat ultramafic lamprophyres and their relation to the North Atlantic Alkaline Province. Lithos, 76(1-4): 491-518.

Tappe, S., Foley, S.F., Jenner, G.A. and Kjarsgaard, B.A., 2005. Integrating ultramafic lamprophyres into the IUGS classification of igneous rocks: rational and implications. Journal of Petrology, 46(9): 1893-1900.

Tappe, S., Foley, S.F., Jenner, G.A., Heaman, L.M., Kjarsgaard, B.A., Romer, R.L., Stracke, A., Joyce, N. and Hoefs, J., 2006. Genesis of ultramafic lamprophyres and carbonatites at Aillik Bay, Labrador: a consequence of incipient lithospheric thinning beneath the North Atlantic craton. Journal of Petrology, 47(7): 1261-1315.

Tappe, S., Foley, S.F., Stracke, A., Romer, R.L., Kjarsgaard, B.A., Heaman, L.M. and Joyce, N., 2007. Craton reactivation on the Labrador Sea margins: ${ }^{40} \mathrm{Ar} /{ }^{39} \mathrm{Ar}$ age and $\mathrm{Sr}-\mathrm{Nd}-\mathrm{Hf}-\mathrm{Pb}$ isotope constraints from alkaline and carbonatite intrusives. Earth and Planetary Science Letters, 256: 433-454.

Tappe, S., Foley, S.F., Kjarsgaard, B.A., Romer, R.L., Heaman, L.M., Stracke, A. and Jenner, G.A., 2008. Between carbonatite and lamproite diamondiferous Torngat ultramafic lamprophyres formed by carbonate-fluxed melting of cratonic MARID-type metasomes. Geochimica et Cosmochimica Acta: in press, doi:10.1016/j.gca.2008.03.008. 